\title{
The Dynamics of Mediterranean Food Cultures in Periods of Globalization
}

\author{
By Paul Claval \\ Colette Jourdain-Annequin ${ }^{\bullet}$
}

The diffusion of food cultures is a fascinating cultural problem since it involves a plurality of mechanisms: (i) the geographical diffusion of plants or animals; (ii) the geographical diffusion of the way to cultivate, process and cook them; (iii) the short and long term migrations of populations, tourists or professional cooks; (iv) the upward or downward diffusion of cooking habits and food tastes; $(v)$ the role of religions, ideologies and fashion in the change of habits. We shall rely on this conceptual framework to compare the processes of standardization at two periods in the Mediterranean World.

Keywords: Mediterranean, Diet, Food Culture, Restaurants, Migration, Tourism, History, Trade.

\section{Introduction}

Globalization means a widening of all aspects of social and economic life to the world scale. It results from the improvement of transportation and communication technologies, is accompanied by new forms of political and economic organization and deeply transforms cultures.

The enlargement of social life to the World scale is a unique event, but there were periods in the past when a somewhat similar process occurred at a lesser scale - the Mediterranean for instance. We shall compare the dynamics of cultures in the Mediterranean through one of its aspects - food cultures (Montanari 2010) - (i) when it was for the first time unified under the impulse of Ancient Greeks and Romans and (ii) at the time of globalization.

The interest for food and diet is rapidly growing since the seventies. It is linked with a stronger concern over food and beverage quality at a time when agriculture increasingly relies on the use of fertilizers, pesticides and genetically modified organisms (Fumey 2008), and when there is a renewed popularity for gastronomy (Pitte 1991 2009, Fumey and Etcheverria 2009).

The diffusion of food cultures is a fascinating cultural problem since it involves a plurality of mechanisms (Claval 2012, Montanari and Pitte 2009): (i) the improvement of transport and communication technologies (ii) the geographical diffusion of plants or animals; (iii) the geographical diffusion of the way to cultivate, process and cook them; (iv) the short and long term migrations of populations, tourists or professional cooks; (v) the upward or downward diffusion of cooking habits and food tastes (Goody 1984); (vi) the role of religions, ideologies and fashion in the change of habits (Pitte 2006).

${ }^{*}$ Emeritus Professor, University of Sorbonne, France.
•Emeritus Professor, University of Grenoble, France.

https://doi.org/10.30958/ajms.4-3-4

doi=10.30958/ajms.4-3-4 
Goody (1984) characterized the dynamics of food cultures in the Eurasian societies of the past as a consequence of their hierarchical social structure; their contemporary transformation resulted from the industrialization of food production and processing.

We shall use a somewhat similar framework to compare the evolution of food cultures of the Mediterranean World in the time of the Greco-Roman civilization and today.

\section{Globalization as a Process of Cultural Confrontation and, Up to a Point, Standardization}

People general think that globalisation started with the Great Discoveries. In fact, it started earlier in the Old Continent. Thanks to navigation, Phœnicians and Greeks got acquainted with the whole Inner Sea coasts at the beginning of the first millennium B. C. With the development of trade, the foundation of ports of trade, then the conquest of the Eastern Mediterranean and Middle East by Alexander, and later, of the whole Mediterranean by Rome, a process of standardization occurred. The Mediterranean had relations with Northern Europe, the Middle East, India and the spices countries. It was also linked to China through the Silk Road. Plants and animals were imported into the Mediterranean from Persia, India or Indonesia during the Ancient Times. In the Mediterranean, the main part of trade and communication was, however, limited to the inner sea and the bordering countries. We shall first focus on this period.

The standardization of cultures progressed later in a wider area thanks to the Silk Road and the extension of the Moslem rule from Spain and Morocco to the West to Malaysia, Indonesia and Western Philippines to the East: the Mediterranean was incorporated into a globalizing area covering the Ancient World from Western Europe, North and East Africa to China, Indonesia, and to a lesser degree, Korea and Japan. The early forms of what became the tropical plantation evolved in the Southern Mediterranean, Egypt, North Africa, Southern Spain, and migrated from there to the Atlantic islands. In the field of animal foods, some of the ways of processing milk were brought by the Western migration of central Asian nomadic groups, Turks for instance, responsible for the spread of yoghurt in the Near East and the Balkans.

The final phase of standardization started with the Great Discoveries. It was for the first time really global. Tomatoes, beans, corn, avocadoes, etc. were imported into the Mediterranean. New beverages came either from America (cacao), Arabia (coffee) or China (tea). All these elements were soon incorporated into the Mediterranean food cultures.

This kind of importation never stopped. It took a new momentum in the $19^{\text {th }}$ and $20^{\text {th }}$ century thanks to the explorations of until then poorly known parts of the World and to the new techniques for transporting plants of animals. Unwanted parasitic microorganisms, plants or animals were also imported, phylloxera for instance.

What was new in the more recent phases of globalization was the diffusion of a wide array of new cultivating, cropping and processing techniques. Relying on mechanization, the use of fertilizers and pesticides, they were not fit to the hilly or mountainous topography of many Mediterranean environments, and relied, in flat areas, on a quantity of water that could only be provided by irrigation or desalinated sea water: hence a dramatic reassessment of the components of the Mediterranean environment. 


\section{The Standardization of the Mediterranean as an Early Phase of Globalization}

The Neolithic revolution diffused the same basic crops (cereal growing, mainly wheat and barley) and sheep and cattle rising all over the Mediterranean and Europe and for some scholars, the same populations. Local diversification occurred later.

Even if cereals were the essential food all over the Mediterranean, the predominant ones were not the same in its Northern, Eastern and Southern parts.

On its Northern shores, the diet was essentially based on barley and hulled wheats as einkorn, emmer, spelt (the botanical ancestor of wheat) or naked wheats as common wheat. For use, they were milled, transformed into flour and cooked as porridges, breads or cakes of every kind (Amouretti 1986).

The Southern shores essentially cultivated durum wheat, which, transformed into semolina, was the basis of couscous, a Berberian meal (keksuor keskesu in Berberian). Its origin was very old, since a couscoussier, a kind of kitchen utensil used for its cooking, was discovered in the tomb of Massinissa (MSNSN on Libyan steles), the first king of unified Numidia, who lived from 238 to 149 B. C.). This Berberian meal survived in domestic cooking during the Roman times; adopted by Arabs, it was introduced in Andalusia in the $12^{\text {th }}$ century (Bolen 1990).

In the Middle East, finally, the durum wheat, cleared of its hull, was partially steam cooked, then crushed and transformed into bulgur (a term of Armenian origin, i.e. from the East or South-East of actual Turkey), so important in Levantine cooking, and today, thanks to Lebanese tabbouleh, well known all over the World.

This evolution gained momentum with the development of Greek civilization, the conquest of Alexander and the extension of Roman domination all over the Mediterranean World. Thanks to them, a deep standardization of crops and food occurred: wine and olive-tree growing became pan-Mediterranean cultures.

\section{Food as a Gift of Gods}

The first question is: what do people know about the food culture during Antiquity? And a first remark comes out: food was, for Greeks, a gift of gods.

In the Bacchants of Euripides, Tiresias told it clearly to Pentheus:

"Know, O my son, that two principles are essential for human beings. First, Demeter, the goddess - or the earth, as you can also name it - feed humanity with dry elements. Then his disciple, the son of Semele, who discovered the fluid juice of the grape, brought it to us in order to sooth the sorrow of the miserable mortals"1.

Later, Menippe, at the table of gods, summed up - and completed at the same time this assertion:

"Demeter gave us the bread, Dionysus the wine and Herakles the meat".

Very often sung by poets or drawn on potteries, the legend of cereal culture is well known: Demeter gave it to human beings to whom she sent the young Triptolemes, bringing an ear of wheat; the gift Dionysus made to human beings is also well known; the role of Herakles, who was the protector of herds and the supplier of meats (he came back from the faraway Erythia with the oxen of Geryon!) is less known. He was, however,

\footnotetext{
${ }^{1}$ Verses 275-285

${ }^{2}$ Lucien, Icaromenippe ou le voyage au-dessus des nuages, 27.
} 
famous as a great eater of meat, he who "in his gnawing hunger was able to engulf the roast and the charcoals at the same time!" ${ }^{3}$ and the mythology was full of anecdotes that signaled him as able to swallow a whole beef ${ }^{4}$.

\section{The Respect of Food Codes}

Another element played a determinant role concerning consuming behaviours: the respect of food codes (Jourdain-Annequin, 2013). They were central to the practices through which the human groups got conscious of themselves, defined their conditions of existence and locate themselves in relation to other groups (these codes could also reveal positions which allowed an individual to affirm himself in front of the city).

The first of the codes imposed by gods was the absolute prohibition of cannibalism:

"Such is the law that the son of Cronos (Zeus) prescribed to human beings, i. e. that fishes, big cats, flying birds devoured one another up to a point when there is no more justice among them, but to human beings, Zeus gave justice which is by large the first of goods"s.

Humankind was distinguished from animals by its condemnation of "allelophagia" (allelo marked reciprocity).

This food codes favoured some foods and, in Greece itself, the "bread eaters", opposed to the "acorn eaters" of mountains that the civilisation of cities did not reach.

In the Mediterranean, the "bread eaters", represented by Ulysses in Odysseus, differed evidently completely from cannibals who the Lestrygons were, but they differed also from the Lotophagites who had flowers as food, and from Cyclops:

"On an excellent soil, Polyphemus did not plough or plant and, even if he raised sheep and goats, he shared nothing with a good "bread eater",

One may understand that to diffuse agriculture could have given the feeling to bring civilization to "Barbarians".

Ritual prescriptions and interdictions defined the norm within the City. They started by the choice of victims offered as a sacrifice to gods: Hera Aigophagos (goat eater) received essentially goats that other deities refused absolutely. Some communities were distinguished by specific interdictions: the Pythagoricians, for instance, did not eat meat and broad beans, a truly Mediterranean plant,was for them forbidden: "Unhappy, much unhappy, from broad bean, keep your hands away", said Empedocles.

\section{The Mediterranean Diet}

More precisely, what was this "Mediterranean diet"? It was evidently diverse and varied from the not envied diet of the soldier "whose haversack smelt onions" to that of the peasant (dry figs, fresh figs, olives and sweet wine, bread tapped on salt, sometimes

\footnotetext{
${ }^{3}$ Athénée, Deipnosophistes, X, 411, c.

${ }^{4}$ In the Argonauts (Philostrates, Imagines, II, 24) or Aristophanes, the Frogs, 506, JourdainAnnequin, C., 1989, Héraclès aux portes du soir. Mythe et histoire, Paris-Besançon, les Belles Lettres.

${ }^{5}$ Hesiod, Works and Days, 276-280.

${ }^{6}$ Odysseus, IX, 190-191.

${ }^{7}$ La Paix, 528-529.
} 
mixed with thyme $)^{8}$, cake of green barley..." Feasts, according always to Aristophanes added to the diet thrushes, hares, grilled broad beans.

More generally, the basis was the sitos: cereals, in all their forms: porridge, bread, pancake (the Greek $5^{\text {th }}$ century B. C. even knew the leavened bread, for which flour was mixed with grape must; at the beginning of the $3^{\text {rd }}$ century A.D., Athénée, in the Deipnosophistai, enumerated 70 types of bread produced in Greece; on the diffusion of bread in Gaul. The opson taken from the common pan was generally made of vegetables, fruits and fish.

Meats were tied to sacrifices, which were, in this way, at the heart of the culinary practices of Greeks (Détienne and Vernant 1979). The myth of Prometheus explained this truly alimentary fraud: men feed themselves on the sacrifices they pretended to offer to gods!

The paintings on potteries showed it: meat was an essential part of the deipnon, this meal that took place before the symposion (among aristocrats) (Schmitt-Pantel 1982).

The Pentaploa that the winner of the race of young ephebes drank during the Athenian Oschophories seemed to us made of five of the typical products of the Mediterranean agriculture: wine, honey, olive oil, cheese, flour.

Two of them really characterized the civilisation brought by the Greeks to the Mediterranean World: olive oil and wine. The impact of cereals (the third component of the Mediterranean trilogy), more widely cropped since the Neolithic revolution, was lesser.

A first approach is that allowed by the linguistic traces they left in the Mediterranean vocabulary: the name of oil was in Greece - and is still for many other peoples - linked to the olive and the olive tree, since olive oil was the only one existing. Their Greek form gave in Latin: oliva, olive tree (elais); olea, olive (elaia); oleum, oil (elaion). These words were borrowed by French as well as Italian, when Spain, more influenced by the long Arabic presence, derived from zit (huile) and zitoun (olive) its terms aceite and aceituna. And the posterity of wine was as wide: oinos in Greek, vinum in Latin, gave vin, vinho, vino (and also wine and wein).

Archaeologists find equally this influence in the artefacts left by the Greek trade: amphoras to transport wine and oil, but also ceramics linked to drinking (cups, craters for mixing wine and water) that prove that the practice of symposia was, also, diffused.

It is, finally, possible to measure this influence through the texts left by the Ancients. In Gaul, for instance, Justin, - who summed up Trogue-Pompée - a Gaul of Vaison-laRomaine, praised frankly the role of Marseilles:

"Under the influence of Phoceans, Gauls got milder and left their barbaric state. They learnt to plough the earth..., to cut the vine and to plant the olive-tree and the progress of things was so bright that it seemed not that Greece had migrated to Gaul, but that Gaul had passed into Greece".

A text, to be certainly analysed in a critical way!

\section{The Evolution of Ancient Cooking}

In its analysis of food habits, Goody (1984: 347-348) opposed two types of civilizations.

\footnotetext{
${ }^{8}$ Acharniens, 835-836.
} 
1- In the first ones (exemplified by sub-Saharan African societies), food was generally consumed close to the place where it was produced. Cooking was mainly a domestic activity essentially practiced by women. It always had a religious and cosmologic dimension that was stronger in the sacrifices made by priests. Food was not used as a mean to get a higher status. 2- In the historical Eurasian societies, food did not lose its religious significance, but was also used as a tool to express and legitimate the hierarchic structure of human relations (either based on castes, orders or classes).

Greek society at the time of Hesiod was in many ways of the first type. Later on, in the $5^{\text {th }}$ century B.C., it kept many of its religious features - the consumption of meat was still largely tied to religious sacrifices. But an evolution had occurred: the symposium, which was an aristocratic form of sociability, was preceded by the eating of meat, and characterized by the consumption of wine, the beverage of Dionysius. Food has become a tool and sign of social differentiation. High cooking began to develop. The process went on in the Hellenistic period.

\section{Trade and the Diffusion of Food and Beverage Consumption and Production}

During the period when Greeks (and Phœnicians) played a dominant role in Mediterranean navigation, trade was the main motor of unification. It was the time when the consumption of olive oil and wine started in Gaul, for instance. Trade was controlled by a port of trade, Massilia and a few less important Greek ports. Customers were, for a long time, the powerful and wealthy aristocracy - the diffusion of food habits was already a downwards social process, even the Keltic social structure was then very different from the Greek one (Poux 2004). Gauls were so fond of Italian wines that it would be the reason for their migration through the Alps, according to Titus Livy or Plutarch:

"Seduced by the flavour of the products of our soil, and in particular by the bouquet of our wines, a pleasure new for them, they had moved through the Alps (Titus Livy, $\mathrm{V}, 33$ ).

This taste was very profitable for the Italian merchants:

"They sent [wine] to them by river or overland and received for it an incredible price: in exchange of a jar of wine, they received a slave, of whom they might make a cupbearer!" (Diodore, V, 26, 3).

For a long time, in Gaul, only the wealthy persons had access to wine; most people consumed a beverage made of fermented wheat and honey: the Korma.

A few centuries later, the situation had evolved: Gauls knew the way to make wine thanks to the Greeks and had developed great wines, as reported by Pliny: he knew good vintage, still ignored by Virgil, the taburnum, the sotanumand the helvicum" that ennobled the province of Viennoise" (the land of Allobroges) and gave to the wine a natural taste of pitch. Unfortunately, these wines cannot withstand transportation: "They are famous in their country, hardly recognizable elsewhere!"

Gauls knew also sophisticated techniques of wine making, that evoked closely those used today for producing straw-wine:

"Among the Voconces, winegrowers keep longer the grape on the vine..., other dry grapes on tiles" (Pliny, Natural History, XIV, 28 and 25-27). 
On the long term, trade had been conducive to the incorporation of the consumption as well as production of wine growing in the outer reaches of the Mediterranean area.

\section{The Diffusion of High Quality Products and the Role of Gastronomy and Early Elite Cooking}

Roman elites considered the way of life of the Hellenistic world as superior to their own and copied it - up to the point that their culture became a Greco-Roman one. In the Western part of the Roman Empire, local elites were seduced by the way of life of the Roman rulers and adopted it.

The standardization of the Mediterranean progressed in this way from the top downwards and from Greece to Rome and the outer limits of the Roman Empire. In such a process, good cooking played a significant role. The aristocracy of Senators and Knights enjoyed high quality food in their Roman residences, in their rural villas or in their second homes in Herculanum, Pompei or Pozzuli. In the late Republican or the Imperial times, they developed the equivalent of Court cooking in monarchic regimes. The table of Lucullus was celebrated at his time - and later on. Three Romans who were famous for their luxury and their taste for good food were more or less confused under the name of Apicius, and a book of recipes (perhaps compiled in the $4^{\text {th }}$ century) was attributed to him (Apicius 1965, André 1961). In the Satiricon of Petronius, the very wealthy Trimalchion, a freed slave, gave an idea (may be exaggerated) of the luxury of some Roman banquets: varied sausages, prunes of Syria, datzs, pomegranates, eggs of peacock, all sorts of poultry, hares, boar, fish in a garum sauce, etc.

Such a variety presupposed knowledge of the food resources of the global world of the time. Trimalchion had imported beehives from Athens in order to produce as good a honey as that of Mount Hymetus. He had written to India in order to get mushroom seeds. His slaves were beaten if they did not use the flour of Sicily, the best in the world. In the field of food as in most others, extended mental maps of the oikoumene are one of the aspects of globalization.

The process had a double geographical dimension: 1- It was conducive to a standardization of the ways of life of the elites. 2- The search of high quality food and beverage brought about a regional diversification of productive areas. A geography of regional specialities developed: Galliccheese that of the high valley of Isère, the Vatisicum, produced by the tribe of Centrons, for instance, was highly appreciated in Rome (Pliny, Natural History, III, 179). People said that the Emperor Antoninus had died from over-eating it (Life of Antoninus, in August History, XII, 4).

Wealthy Romans liked in a similar way the salted meat of pork coming from the Po valley and Gaul.

The search for quality had especially strong effects on wine production. Pliny mentioned 195 good wines in the Mediterranean, the majority of them produced in Italy: falerno in Campania, rhetico of Sondrio or pucinum close to Aquilea in Northern Italy (Tchernia 1986 1999). Strabo considered the wine of Chio as the best of Greek wines... (ibid.: 218).

The building of the huge unified area that was the Mediterranean in Greek and Roman times was, in this way, conducive to the diffusion of a form of high cooking, which was a sign of the acceptance by local elites of a general model of behaviour. This process was also responsible for the specialization of some areas in the production of luxury foods or beverages, and their trade over wide areas. 


\section{The Limits of Food Standardization in the Ancient Mediterranean}

Food standardization remained, however, limited during Ancient times. It did not concern the lower part of the population, who had to live on the local resources.

A good part of the wheat Rome needed came from Southern Mediterranean areas either Sicily, Egypt or the province of Africa (Tunisia and Eastern Algeria today). Some of the most spectacular Roman ruins are found today in Moracco (Volubilis), Algeria (Timgad), Tunisia (Carthago, El Djem) or Libya (Leptis Magna). Local elites were living according to the upper class Roman model, as showed by the mosaics in the Bardo Museum in Tunis. But the persistency of native Berberian forms of cooking - the use of semolina for couscous - is a proof of the limited impact of higher forms of culinary habits on the lower classes of the Empire periphery.

\section{The Role of Religious Beliefs in the Diversification of Mediterranean Food Habits}

Food habits cannot be analysed only in terms of the availability of vegetal or animal products. They are part of the whole complex of features characterizing cultures. The religious or ideological beliefs of groups have thus an important impact on the ways of eating and drinking. Judaism, Christianity and Islam, the three monotheisms that took the place of ancient paganisms, prohibited the consumption of some food or beverage. They contributed to the diversification of food use the Mediterranean during the first millennium A.D.

Christianity made the consumption of bread and wine central to the celebration of the mass sacrifice, and ordered long periods of fast, when eating meat was prohibited and fish took its place. The diffusion of Christianity favoured in this way the diffusion of wine and bread consumption. From the sixteenth century, it explained the importation of salted or dried cod in all the Christian part of the Mediterranean, since the halieutical resources of the Mediterranean sea were insufficient.

Islam prohibited the consumption of wine and pork meat, introducing in this way a deep opposition between Mediterranean peoples, even if they relied on the same array of food resources - even if there are few differences between the Christian Greek cooking and the Moslem Turkish one.

\section{Contemporary Globalization and the Mediterranean}

Contemporary globalization is a result of a process that started with the Great Discoveries and took momentum first at the time of industrial and transportation revolutions, in the nineteenth century, and then with the progress of rapid transportation, telecommunication and computing since mid $20^{\text {th }}$ century.

\section{The Early Phase of Globalization and Mediterranean Food Habits}

\section{The Role of Plants and Animal Diffusion}

The first consequences of globalization were the introduction in the Mediterranean of plants, which were incorporated into its systems of cultivation and transformed deeply its food habits. What would be Italian cooking without tomato, or North African one without harissa (made of chilli)? The impact of maize was also important in some areas, but limited elsewhere by the summer drought of most of the Mediterranean. 
Mediterranean plants were at the same time introduced in the other areas of Mediterranean or sub-Mediterranean climate all over the World. The diffusion of olive tree remained limited. That of vine started in the $16^{\text {th }}$ century (Chili), $17^{\text {th }}$ (Cape colony), $19^{\text {th }}$ (California, Western Argentina) and became massive in the $20^{\text {th }}$ (Australia, New Zealand). It transformed deeply the geography of good wine production.

The Spanish and Portuguese settlers discovered that it was possible to raise flocks of sheep and herds of cattle in a good part of Latin America in order to produce meat, leather or wool. Hence the transplantation of Mediterranean cattle raising techniques and meat consumption habits in Latin America and up to a point, in Western United States, since American cattle raisers incorporated a good part of Texan know-hows in that field.

\section{The Role of International Migrations in the Early Phases of Globalization}

Migrations of populations were permanent in the Mediterranean World. In the $16^{\text {th }}$ and $17^{\text {th }}$ centuries, they were largely centred on the Iberian Peninsula. Spanish settlers moved to the West Indies, Mexico, Central America, Venezuela, Columbia, Peru, Bolivia, Chili and to a lesser degree, Argentina. Portuguese moved to Brasil. Most of them had, however, to change their food habits in so far that it was impossible to grow wheat and to produce wine in most of these regions. The farinha of cassava took the place of semolina in Brazilian cooking, for instance.

At the time groups of Jewish or Moslem refugees moved do Italy, Morocco, the Turkish Empire and for a part of Jews, the Netherlands.

Spain was at the same time attractive because of its high incomes: many French bakers from Auvergne settled in Madrid and central Spain, for instance, during the $17^{\text {th }}$ and $18^{\text {th }}$ centuries.

These movements of populations were important, but their impact on food habits was a limited one, except in Latin America.

\section{The Downward Diffusion of Food Habits: From Aristocratic to Bourgeois Societies}

The downward diffusion of eating and drinking habits was active during the Middle Ages. Since in the Mediterranean, it was possible to grow high quality cereals, pulses, vegetable and to produce meat and good wine in most plains or hilly countries, this process did not induce, during the Middle Ages, a strong geographical diversification of productions. As explained half a century ago by Emilio Sereni (1961), this evolution was only responsible for the development of a ring of bel paese all around the cities: well-to-do urban dwellers ownedthere the luxury mansions where they spent summer time; farms in these areas were producing high quality vegetables, fruits and wine.

Specialization in high quality wine production occurred only near the areas where it was impossible to produce wine - the Rioja vineyard of the Ebre valley developed in this way at the time when the Spanish Court was moving from city to city in Old Castile, too cold for vine. A few quality vineyards developed also along the Mediterranean coasts in the late Middle Ages and Modern Times. Venetian merchants marketed in this way Greek wines through the port of Monemvasia, in Peloponnese - hence their name of malmsey wines. In Southern France, the little port of Frontignan exported a good quality muscatel wine.

Social hierarchies were reinforced during the $16^{\text {th }}$ century. The process was especially strong in Spain and Italy. It was characterized by an increased emphasis on table manners. Marriages among aristocratic or royal families were in this way responsible for the early diffusion of Italian court cooking in the Western capital cities, Paris more particularly, 
thanks to two queens, Catherine de Médicis and Marie de Médicis in the sixteenth century. As a result, Paris became the main centre of elaboration and diffusion of French cooking.

Western societies were changing during the $17^{\text {th }}$ and $18^{\text {th }}$ centuries. There were still aristocratic, but thanks to trade and the development of cottage industry, bourgeoisies played a growing role. They copied the modes of life of the nobility. Amsterdam or London began, in this way, to reorganize the production of luxury food and beverage at the European and up to a point, World scales.

At the European scale, English or Irish merchants played a central role in the fortunes of the vineyards of Bordeaux, Porto, Madeira, sherry, in the production of oranges in Spain, citrus in Sicily, raisins in Malaga, currants in Greece, sultanas in Turkey. At the World scale, the Dutch India Company created the Constancia vineyard near Capetown, and developed coffee production in Java. British East India Company imported tea from China and later introduced its production in India and Ceylon. These companies were instrumental in supplying these produces to Western Mediterranean countries.

At the end of the $18^{\text {th }}$ century, the food habits of the Mediterranean countries have already ceased to be relyon Mediterranean productions and food models.

In the downwards diffusion of food habits in bourgeois societies, a new institution played an important role from the end of the $18^{\text {th }}$ century: the restaurant (Huetz de Lemps and Pitte 1990). First appeared in Paris in the 1770s, the French Revolution accelerated its multiplication: the cooks of the dukes or counts beheaded by the Terror opened restaurants! High cooking began in this way to be accessible to wider social groups. The diffusion of this new form of eating facility was rapid all over the world.

\section{Aristocratic and Middle-Class Tourism and the Image of the Mediterranean}

Tourism played an increasing role in the dynamics of the Mediterranean. At the beginning, from $16^{\text {th }}$ to the $19^{\text {th }}$ century, it was mainly practiced by young British aristocrats making the Great Tour to Italy in order to get acquainted with Roman or Renaissance arts. Even if the journey was only carried out by few persons, it had important consequences. It popularized Palladian models of architecture in Great Britain, made famous Claude Lorrain landscape paintings and inspired English $18^{\text {th }}$ century landscape architects as William Kent. It contributed to the curiosity for nature and in the $18^{\text {th }}$ century, for sublime.

The impact of this tourism was all the more important that its results were diffused through books of souvenir or travel and engravings or paintings. Mediterranean (and more precisely, Italian) scenery of past and present time became attractive. Before getting seduced by Italian pasta, people learnt about Italian wines.

In this way, and for the first time, the image of a foreign country was diffused all over Britain and, up to a point, among European elites. When the cost of travelling decreased, Italy, Spain, the Holy Land, and to a lesser degree, Greece and Egypt attracted a growing number of middle-class tourists. Following the initiative of Thomas Cook, travel agencies made easier the organisation of itineraries. Newspapers gave vivid reports on the daily life in Venice, Florence, Tuscany, Rome and Naples, their coffee shops, their restaurants etc. Thanks to the media, the image of Mediterranean food, its flavour, its smell was popularized. 
The Industrial Revolution, the First of Acceleration of Globalization and Mediterranean Food Habits

The Role of Mass Migrations

In the past, mass migrations resulted mainly from the movements of whole tribes or peoples leaving their homelands in order to settle in new environments - Gauls moving from actual France to the Po valley or Galatia in Turkey, Geman tribes invading the Roman Empire. Later on, work migrations were mainly the fact of young or middle aged male adults, since travelling with a family was difficult - hence the role of cross-breeding in most colonial settlements from the $16^{\text {th }}$ to the $19^{\text {th }}$ century.

An acceleration of globalization occurred in the second half of the $19^{\text {th }}$ century as a result of the industrial revolution. Thanks to railways and steamers, travel became much cheaper and safer: hence the development, from the 1840s, of mass migrations from overpopulated rural regions towards European industrial areas or the new lands of North and South America, South Africa, Australia, New Zealand or Siberia.

The Mediterranean did not benefit directly from the industrial revolution. From the 1870s, emigration from Italy, Spain, Portugal and to a lesser point, South-East Europe, Romania and Southern Russia grew rapidly. By the end of the $19^{\text {th }}$ century, Turkey, Syria and Lebanon participated in the movement.

Migrants kept a part of their culture in the countries where they settled. In the neighbourhoods where they congregated, ethnic restaurants were soon created: hence a new form of diffusion of food cultures: it ceased to be mainly linked to a downward social process. Ethnic restaurants became to attract low or middle class local consumers. Italian pasta or pizza attracted a wide array of clients: they were cheap and tasty.

\section{Within the Mediterranean: International Ports and Colonization}

The acceleration of globalization in the second half of the $19^{\text {th }}$ century had an important impact on the Mediterranean World. Since Antiquity, navigation had been mainly a seasonal activity. Thanks to steamers, it became active all year round. The opening of the canal of Suez transformed the Mediterranean into one of the major World maritime route.

Mediterranean ports throve. Their population became a cosmopolitan one: they attracted native rural populations, local or foreign Jews, Greeks, Italians, French and Englishmen: Salonica, Istanbul, Alexandria, Trieste, Genoa, Napoli, Livorno, Marseilles, Algiers, Tunis developed in this way. Western seamen or traders became in this way accustomed to Oriental tabbouleh, North African couscous, Italian pizzas or pasta, Marseilles bouillabaisse, Valencian paella etc.

The Southern and Eastern shores of the Mediterranean were colonized. It started with Algeria in 1830, Tunisia, Cyprus and Egypt in the 1880s, Libya and Morocco at the beginning of the $20^{\text {th }}$ century. The protection of Christians had created a semi-colonial situation within the Ottoman Empire in Lebanon and Holy Land.

Because of colonial administrations, intercultural relations became more numerous and deeper, even on an unequal basis. Colonizers employed frequently native servants, who learned Western cooking, but also introduced local produces and recipes in the dishes they prepared for their masters. In all North Africa, French bread became the main staple for urban natives. 


\section{The Contemporary Phase of Globalization and Mediterranean Food Habits}

Globalization went on during the first half of the $20^{\text {th }}$ century, but the two World Wars slowed it down: interoceanic mass migrations were much reduced. Even if the United States were the first economy, their economic expansion remained mainly selfcentred. Some evolutions were, however, important since they prepared what happened after 1950 or 1960 - the contemporary phase of accelerated globalization, caused by the revolutions of rapid transportation, telecommunication and computers, by improved distribution techniques and by the role of new media in the field of communication. The free trade policy that was central at the world scale until the last few years stimulated it.

\section{The Development of Mass Tourism}

Until the beginning of the $20^{\text {th }}$ century, tourism was mainly practiced by the upper classes. Thanks to their higher income, some British blue collars began to visit the big sea resorts of Brighton or Blackpool by 1900, but the main changes occurred later, in the 1920s and 1930s. Tourism was mainly centred on the visit of historical or art cities, or on winter stays in mild climate Rivieras. From 1900 on, more sportive forms of tourisms developed: skiing completed aristocratic mountaineering; a new cult of sunshine and open air activities drove a multitude of visitors to the Mediterranean shores or to Florida and the Caribs in summer time.

The democratization of tourism progressed in the interwar period and accelerated after World War Two. For Northern people, the frequentation of Mediterranean seaside resorts became easier thanks to the use of cars and, from the 1950s and 1960s, regular and low-cost flights.

For the majority of European population, the Mediterranean ceased to be essentially an image and a dream. It became a reality for a few weeks every year. It allowed the direct consumption of Mediterranean produces in local restaurants: fruits, olives, fish and sea food, wine. At a time when people got more conscious of their health, the Mediterranean diets became popular. Was not it true that in many rural Mediterranean places - Crete for instance - people became older than in more industrialized and urban "developed" societies thanks to the regular consumption of bread, vegetables, garlic, cheese and yoghourts, olive oil and wine?

Mediterranean food habits became popular among European and North American societies. Ethnic Italian, Greek and to a lesser degree, Spanish, Portuguese, Turkish or Lebanese restaurants spread in a few decades all over the developed World - and farther.

\section{A New Structure of Information Diffusion}

The diffusion of Mediterranean food habits ceased in this way to result mainly from a downward social process: from the Mediterranean high classes to their extra-Mediterranean equivalents and then, from these ones to extra-Mediterranean middle or lower classes. The diffusion of information ceased to result mainly from the travels of well-to-do persons and the publication of guides and travel books. It resulted increasingly from the visit of lower income people to the Mediterranean and the opening of ethnic restaurants by cooks or restaurateurs coming from the Mediterranean World. It was increasingly broadcast by radio, movies, television and modern magazines. In this way, the social networks along which food habits were diffused became much less hierarchized than in the past and relied on the new forms taken by communication. 


\section{$\underline{\text { A New Phase of International Mass Migrations }}$}

International mass migrations developed again rapidly after World War Two: they were initially a direct consequence of the conflict, with millions of Germans moving back to their severely reduced country or Polish people accompanying the westward move of their national territory. Some of these moves took place in the Mediterranean World: Italian speakers were expelled from the Dalmatian coast, Jews from all over the world, but mainly from Europe, converged towards Israel.

The next phase occurred rapidly: workers from the Northern Mediterranean countries (Portugal, Spain, Italy, Yugoslavia, Greece, Turkey) migrated towards industrial Europe (France, Belgium, the Netherlands, West Germany, United Kingdom and later on, Sweden), or overseas (United States, Canada, Latin America, Australia). These migrants created ethnic food restaurants in their new countries. In Australia, where food habits were still mainly British, they played an important role in the diffusion of Mediterranean food and wine production and consumption.

With the end of the colonial rule, one million Frenchmen who lived in Morocco, Tunisia and Algeria moved back to France in the late 1950s and early 1960s, importing a part of the food habits they had taken in North Africa - Spanish chorizo and paella, Italian pasta and sea food, North-African couscous and harissa. With the former French soldiers who have stayed in this area, they were responsible for making couscous one of the most popular French dishes today.

This pattern of international migration changed in the 1970s. National employment in North Mediterranean countries had grown rapidly thanks to industrialization and tourism. Natality dropped dramatically in less than two decades. Portuguese, Spanish, Italian and Greek people ceased to migrate. The relay was taken by South Mediterranean countries, where demographic expansion was rapid. Lebanese, Syrians, Palestinians and Egyptians moved mainly towards Saudi Arabia and the Gulf emirates, and up to a point for Egypt and Tunisia, towards Libya. From North Africa, migrants moved first to France and then to Belgium, the Netherlands, Germany, and later, to Spain and Italy. They contributed to the introduction of South Mediterranean food habits in Western Europe.

Today, the South-North flow of migrants through the Mediterranean sea is increasingly made of sub-Saharan Africans who sought employment and security. They came mainly through Libya since the fall of Khadafi's dictatorship, or through Morocco.

\section{Changing Food Economy and Consumption Behaviour}

Globalization was conducive to the diffusion of Mediterranean produces and food habits all over the World: when I first visited Taipei, for instance, in 1988, restaurants were either Chinese (with a wide variety of regional traditions, from Beijing, Sichuan, Canton, etc.) or Japanese. Today, there are many Italian and Greek restaurants and a lesser number of French ones. Italian cooking is very popular over all Europe, both North and South America and in Australia, and present in the Far East.

The kind of cooking that is exported is not the same according to countries. What is exported from France remains generally high cooking - with a few more popular forms, as crêperies from Brittany. The international brand of Italian cooking relies mainly on popular Italian food - pasta and pizza: it uses cheap produces (wheat semolina and flour) as basic ingredients and can be easily adapted to modern fast food habits. High quality Tuscan cooking relies on expansive produces and requires more sophisticated preparations. It was central in the culinary influence of Italy in the $16^{\text {th }}$ and $17^{\text {th }}$ influence. Today it is hardly known outside the Italian peninsula (Montanari 2002). The situation is similar for Italian wines: the best vineyards of Piedmont (Barolo or Bardolino) and Venetia are 
mainly known and consumed in Italy. What is exported comes from the medium quality vineyards of chianti (more famous abroad a century ago than today), in Tuscany, or the prosecco ones in Friuli and Venetia.

The international success of prosecco is recent - the growth of exportations occurred mainly after 2000: it is a relatively cheap and generally dry sparkling wine; it is widely used in the preparation of trendy cocktails. It means that it is not appreciated for its Mediterranean qualities, but according to a new standard oftaste promoted by the contemporary jet society and diffused by globalized mass media.

The Greek muscatel wine of Samos has benefited from a somewhat similar promotion a few years before as an aperitif.

Mediterranean food and beverage is thus transformed according to global new ways of life, the growing part of fast food and deeply transformed produces. Industrialization has favoured the diffusion of Italian pastas and pizzas, Parmesan cheese, and mozzarella. In France, it allowed for the success of couscous - its preparation at home takes hours.

In this respect, some aspects of traditional Mediterranean food habits are today internationally appreciated - the Spanish tapas, this form of appetizer eaten when having a drink in a bar: it is one of the main attraction for tourists in Spanish sea-resorts.

\section{Threats on Mediterranean Food Production and Consumption Patterns}

Contemporary evolution of Mediterranean food culture bear witness to the success of Mediterranean produces, cooking and diet all over the world. But this evolution is not totally positive.

Even if during the last forty years, a new interest has appeared for safeguarding the quality of traditional Mediterranean produces, there are many threats. A part of these productions grew in hilly or mountainous areas, on poor soils: even if very tasty, their yields were low. It is increasingly difficult to exploit such environments since it is too costly. A growing part of Mediterranean produces came from coastal plains or flat inland plateaus; many are irrigated; heavy doses of fertilizers and pesticides are used. It is true for vegetables and fruits - hence a decline in the quality of these produces.

The success of specifically Mediterranean production resulted in a steady increase of the surfaces where there are grown, and a correlative reduction of other crops - cereals or dry vegetables. The Mediterranean countries depend increasingly on the importation of their basic food.

The demand for fish and sea-food is very high among local populations and tourists. The Mediterranean Sea is not very productive: overfishing is exhausting its resources.

Olive oil was one of the bases of Mediterranean diet. Its production reaches a maximum. As a result, it is expensive. An increasing part of Mediterranean populations are relying on imported low cost and generally, low quality oils.

Fast food always played an important role in Mediterranean food habits - there were everywhere equivalents to Spanish tapas. Today, they are increasingly substituted by international fast food - junk food, in fact, most of the time.

In its contemporary forms, globalization affects in two ways the Mediterranean food habits: it contributes to its diffusion of some of its component all over the world. In spite on the growing emphasis on the consumption of quality produces, it robs of their originality a good part of Mediterranean produces and dishes. 


\section{Conclusion}

The analysis of food habits at the time when globalization (either a partial or planetary one) occurred (or occurs) shows that there are (or were) few processes at work in this field: diffusion through the migration of whole populations, or a part of them (for labour or tourism), through hierarchical social relations (generally, downwards ones), through horizontal social relations (as in the case of trade or mass tourism) and through the diffusion of news, narratives, oral messages or movies and images.

All these mechanisms were present in the past as well as today, but they were differently structured. At the time of the first unification of the Mediterranean World, trade was certainly essential, even if the adoption of new consumption habits was linked to the existence of strong social hierarchies - especially in the receiving societies. Later on, the evolution was accelerated by the development of direct power relations in the Hellenistic World and then in Rome. A part of transfers came also from less direct power relations: the slave trade and the way slaves were used, or the custom to force neighbouring rulers to send their sons in Rome as hostages. The success of the diffusion of Roman food habits came mainly from the prestige of the Roman elite and the will to copy it.

The success of Mediterranean food habits during the long-term process of contemporary globalization was linked to the specificities and quality of its cattle breeders and sheep or goat farmers, its cereal producers, its fruit and wine growers and its bee keepers. It came also from the diversity of sea food it produced.

In its first phases, this success was insured by diffusion processes based on mass movements of populations (migrations essentially), higher class tourism, movements of specialists (cooks) and familial ties within European aristocracy. In this phase, diffusion was facilitated by strong hierarchical structures, along which culinary fashions moved down from aristocrats to their clients or servants or from opinion leaders (writers and later journalists) to their readers.

In its later phases, mass tourism added its effects to mass migrations. The role of traditional forms of hierarchical diffusion lessened. Hierarchical diffusion did not disappear, but traditional nobility, landed aristocracy, businessmen on the social side, and scholars on the intellectual one, have ceased to be at the highest social level. As shown by Nathalie Heinich (2012), we are living in a society of visibility: in such a society, what matters is not the things people do, but the way they manage to be permanently interviewed, photographed, filmed, present in the telephone news and attracting huge number of fans on social networks.

In the field of food culture, there were always close relations between popular and high cultures, since servants and cooks working in bourgeois or aristocratic families came generally from the lower or middle classes.

These relations began to change when intellectuals began to reflect upon food habits, in the early $19^{\text {th }}$ century. One of the privileges of the national elites had been to eat high quality products prepared according to the codes of high cooking. A curiosity for other food cultures - either high or low - in his own country, or foreign ones, then developed. Gastronomic tourism began to be codified when Michelin published its guide of French high quality restaurants at the beginning of the $20^{\text {th }}$ century.

This evolution speeded up in the second half of the $20^{\text {th }}$ century when food became the object of many books, movies or T.V. shows. Eating "ethnic" food became a substitute, or complement, to travel. At a time when mass cultures were responsible for the ever wider use of junk food, consuming high cooking became a dream and a way to accede to a higher sphere of culture. At a time when the traditional forms of civilisation had lost a part of their aura, it opened a path towards a new civilisation, where the bases of daily food 
would be questioned, and where a new form of high culture would be shaped through the achievement, among other aspects, of new forms of high food.

In this process, the Mediterranean played an important role. France has ceased to be the main centre of Western high cooking. Italy, Spain and to a lesser degree Portugal and Greece - but also Lebanon or Morocco - display a remarkable inventiveness in this field. But other processes are operating at the same time: this model of cultural promotion through quality cooking is in competition with the model promoted by the jet society, by that centred on fast food. For economic and cultural reasons, this last one is very dynamic. It contributes to the alter the Mediterranean diet and to popularize junk food in the Mediterranean societies.

\section{References}

Amouretti MC (1986) Le Pain et l'huile dans la Grèce antique. De l'araire au moulin [Bread and oil in ancient Greece. From the araire to the mill]. Paris: les Belles Lettres.

André J (1961) L'Alimentation et la cuisine à Rome [Food and cooking in Rome]. Paris: Klinksieck.

Apicius (1965) L'Art culinaire, trad. de Jacques André [Culinary Art, trad. from Jacques André]. Paris: les Belles Lettres.

Bolen L (1990) La Cuisine andalouse: un art de vivre. XI ${ }^{e}$-XIII siècle [Andalusian Cuisine: a way of life 11th-13th century]. Paris: A. Michel.

Claval P (2012) Géographie culturelle, $3^{\text {rd }}$ ed [Cultural Geography]. Paris: A. Colin.

Détienne M, JP Vernant (1979) La Cuisine du sacrifice en pays grec [The cuisine of sacrifice in Greek country]. Paris: Gallimard.

Fumey G (2008) Géopolitique de l'alimentation [Geopolitics of food]. Auxerre: Edition des Sciences humaines.

Fumey G, O Etcheverria (2009) Atlas mondial des cuisines et gastronomies [World Atlas of Kitchens and Gastronomy]. Paris: Autrement.

Goody J (1984) Cuisines, cuisine et classes [Cooking, Cuisine and Class]. Paris: Centre Pompidou éd.

Heinich N (2012) De la Visibilité. Excellence et singularité en régime médiatique [Visibility. Excellence and singularity in the media regime]. Paris: Gallimard.

Huetz de Lemps C, Pitte JR (1990) Les Restaurants dans le monde et à travers les âges [Restaurants in the world and through the ages]. Genoble: Glénat.

Jourdain-Annequin C (2013) Quelques réflexions sur le comportement alimentaire des Grecs anciens [Thoughts on the eating behavior of ancient Greeks]. Actes du Congrès de Rennes du C.T.H.S. Paris: C.T.H.S.

Montanari M (2010) Le Manger comme culture [Eating as a culture]. Bruxelles: Editions de l'Université de Bruxelles.

Montanari M (2002) La Cuisine italienne [Italian food]. Paris: le Seuil; éd.

Montanari M, Pitte JR (eds) (2009) Les Frontières alimentaires [Food Borders]. Paris: CNRS Editions.

Pitte JR (1991) Gastronomie française. Histoire et géographie d'une passion [French gastronomy. History and geography of a passion]. Paris: Fayard.

Pitte JR (2006) Le Vin et le divin [Wine and the divine]. Paris: Fayard

Pitte JR (2009) Le Désir de vin [The desire of wine]. Paris: Fayard.

Poux M (2004) L'Age du vin. Rites de boisson, festins et libations en Gaule pré-romaine [The Wine Age. Rites of drink, feasts and libations in pre-Roman Gaul]. Montagnac: M. Mergoil. 
Schmitt-Pantel P (1982) La Cité au banquet. Histoire des repas publics dans les cités grecques [The City at the banquet. History of public meals in Greek cities]. Paris: Plon.

Sereni E (1961) Storia del Paesaggio agrario italiano [History of the Italian agricultural landscape]. Bari: Laterza.

Tchernia A (1986) Le Vin de l'Italie romaine [The Wine of Roman Italy]. Rome: Ecole française de Rome.

Tchernia A (1999) Le Vin romain antique [The ancient Roman wine].Grenoble: Glénat. 
